\title{
Characteristics of Students' Metacognition Process at Informal Deduction Thinking Level in Geometry Problems
}

\author{
Ahmad Rofii, Sunardi, Muhtadi Irvan \\ Universitas Jember, Jalan Kalimantan No. 37, Kampus Tegalboto, Sumbersari, Jember, Indonesia \\ e-mail: ahmadrofiis2p.mtk@gmail.com
}

\begin{abstract}
Abstrak
Penelitian ini bertujuan untuk mengetahui karakteristik proses metakognisi siswa pada tahap berpikir deduksi informal dalam menyelesaikan masalah geometri. Penelitian ini merupakan penelitian deskriptif kualitatif. Sebanyak 66 siswa SD dites kemampuan berpikir geometri Van Hiele untuk dikelompokkan sesuai dengan tahap berpikir geometri. Siswa yang berada pada tahap berpikir deduksi informal kemudian diminta memecahkan masalah geometri. Selanjutnya dilakukan wawancara untuk menggali karakteristik dari proses metakognisinya. Berdasarkan analisis data urutan karakteristik dari proses metakognisi adalah lengkap melalui proses perencanaan, monitoring dan evaluasi. Indikator proses metakognisi tersebut muncul pada setiap komponen pemecahan masalah, mulai dari memahami masalah, menyusun rencana pemecahan masalah, melaksanakan rencana pemecahan masalah hingga memeriksa solusi yang diperoleh.
\end{abstract}

Kata Kunci: Metakognisi, Deduksi Informal, Permasalahan Geometri

\begin{abstract}
This study aims to determine the characteristics of students' metacognition process at the level of informal deduction thinking in solving geometry problems. This research is a qualitative descriptive research. 66 elementary students were tested about their thinking ability of Van Hiele geometry by dividing them into some groups according to their geometry thinking level. The informal deductive thinking level group was tested for problem-solving geometry. Furthermore, interviews were conducted to explore the characteristics of their metacognition process. Based on the data analysis, the characteristics sequence of the metacognition process is complete through the process of planning, monitoring, and evaluation. The metacognition process indicator appears in each problem-solving component, from understanding the problem, preparing a problem-solving plan, implementing a problem-solving plan to check the solutions obtained.
\end{abstract}

Keywords: Metacognition, Informal deduction, Geometry problem

How to Cite: Rofii, A., Sunardi, \& Irvan, M. (2018). Characteristics of students' metacognition process at informal deduction thinking level in geometry problems. International Journal on Emerging Mathematics Education, 2(1), 89-104. http://dx.doi.org/10.12928/ijeme.v2i1.7684

\section{INTRODUCTION}

Mathematics becomes a part of learning in school that has important roles and functions. It is related to the direct object of mathematics in building facts, concepts, operations, and principles. Gagne in Purnomo (2017) states that the direct object of mathematics is related to the ability of logical thinking, problem-solving, analytical thinking, positive-thinking to mathematics, dilligent, discipline will implicitly be obtained if someone learns mathematics. The statement means facts, concepts, operations, and principles as objects learned in mathematics can be done through learning. In line with the statement of Duffin and Simpson (2000), understanding the concept as a mathematical object owned by a person is expected to express his 
understanding and communicate to the source of learning so that he can answer the problems given when he has mastered the concept. Elementary School is an appropriate means to build the concept of mathematics, especially the concept of geometry.

Geometry learning which has been done only gives awakening and its characteristics to solve the problems given without exploring the students' thinking process in recognizing and developing the concepts which they obtain. Geometry occupies a special position in the mathematics curriculum because many of the concepts contained in it. From a psychological point of view, geometry is the presentation of abstractions from visual and spatial experiences. While from a mathematical point of view, geometry provides approaches for problem-solving. Clements and Battista (1992) and Ikhsan (2008) suggest that in learning geometry, someone will go through five levels in a hierarchical manner known as Van Hiele geometry, level 0 (visualization), level 1 (analysis), level 2 (informal deduction), level 3 (deduction) and level 4 (rigor).

Polya (1973) defines problem-solving as a very high intellectual activity because the student must be able to solve the problem by using the rules learned to make the problem formulation through steps; understanding the problem, developing a plan of completion, implementing a settlement plan and rechecking. Yeo (2004) explains that solving a problem depends on five factors, including the details, skills, knowledge or concepts, metacognition process, and deeds.

Metacognition in the thinking process is the student's awareness of his thinking process, checking his thinking process and regulating his thought processes (Wilson \& Clarke, 2004). Metacognition ability is a person's ability to control the thinking process. The thinking process usually occurs when learning activities take place so that metacognition ability is closely related to students' learning activities. In relation to learning mathematics, metacognition can play a role in helping students to solve a problem. Schoenfeld (1992) suggests that difficulties in solving problems related to students' inability to observe and control their metacognition processes. The process can occur when the learning activities are implemented. This means that metacognition ability is closely related to students' learning activities. Latifah (2010) states that students choose a strategy, monitor the learning process, correct the errors, analyze the effectiveness of learning, then those activities are considered as learning activities that require metacognition ability.

Several studies related to the students' metacognition process in mathematical problem-solving have been done. Among them are Wilson and Clarke (2004), Panauorra (2009), Kuzle (2011), Karan and Irizary (2011), In'am et al. (2012), Zainal \& Tajudin (2013), Abdullah and Zakaria (2013), Weldana (2014 ), In'am (2016), Purnomo et al. (2016) and Purnomo et al. (2017). These studies are generally focused only on the process and characteristics of students' metacognition in solving mathematical problems. However, the study has not focused on issues that adapt to the students' thinking levels in solving geometrical problems especially in the informal deduction phase. The geometric thinking level is interesting to be observed because at this level students have been able to see the correlation of the properties on a geometry form and interface by using informal deduction and can classify at the forms hierarchy. In this study, the researcher will analyze and describe the characteristics of metacognition process of elementary school students at the level of informal deduction thinking in solving geometry problems. The Character of the students' metacognition process is described based on the planning process, monitoring and

IJEME, Vol. 2, No. 1, March 2018, 89-104. 
evaluating which are included as the components of metacognition in solving mathematics problem based on criteria stated by Polya.

\section{Definition of Metacognition}

Livingstone (1997) defines metacognition as thinking about thinking which means metacognition is a person's thinking ability that happens on themselves. Matlin (1998) states that metacognition is the knowledge, awareness, and control of the cognitive processes that occur in our self. William Peirce defines metacognition in general and in particular. According to Peirce (2003), metacognition is thinking about thinking. While specifically, Taylor states that metacognition is an appreciation of something already known to make the right conclusions about how to apply a strategy about a particular situation and do it accurately. Kafoussi (2013) states metacognition is the ability of a person to observe and control himself/herself against a problem known. During the mathematics learning, the most important are the students' metacognition process in solving problems related to mathematics. According to Suherman (2001), metacognition is an ability to realize what students know about themselves as learners, so that he can control and adapt his behavior optimally.

Flavell (in Haryani, 2012) mentions the reasons for the necessity of developing metacognitive abilities, among others: (1) students' thinking is sometimes wrong and tends to be different, and in this circumstance it requires good self-monitoring and regulation, (2) students must be able to communicate, explain and provide clear reasons for their thinking to other students as well as to themselves, (3) to survive and succeed well, students need to plan what they will do and critically evaluate other plans; (4) if students must make a tough decision, it will require metacognition skills.

Based on several definitions that have been described, it can be identified the main points of the definition of metacognition: (1) metacognition is the ability of the soul included in the group of cognition, (2) metacognition is the ability to realize and to know his cognition process that happens to himself, (3) metacognition is the ability to direct the cognition process that happens in own self, (4) metacognition is the ability to learn how should be learned which includes the planning process, monitoring and evaluating, (5) metacognition is a high-level thinking activity because the activity is able to control the thinking process that is going on ourself.

\section{Metacognition Components}

Foong and Ee (2002) argue that teaching through the giving of problems provides an opportunity for students to build mathematical concepts and develop their math skills. To solve the problem, students should observe, connect, ask questions, find reasons and draw conclusions. Success in solving problems is closely related to the student's thinking process and his metacognitive ability level. Flavell, as quoted by Livingstone (1997), states that metacognition consists of metacognition knowledge and metacognition experience/regulation. Flavell further divides metacognition knowledge into three variables, namely: (1) individual variables, referring to the knowledge of people, human (self as well as others) have limitations in the amount of information that can be processed, (2) task variables, about tasks that contain knowledge that some conditions often lead to a person being more difficult or easier in solving a problem or completing a task and (3) strategy variables, including knowledge of strategies and knowledge of how to do something or how to overcome difficulties. While Woolfok (2008) describes in detail about the metacognition experience of the three processes in metacognition strategies as follows: (1) the 
planning process, is a decision about how much time spent in solving the problem, what strategy will be used, what sources need to be collected, how to start, and which to follow or not to do first, (2) the monitoring process, is a direct awareness of how we perform a cognitive activity. The monitoring process requires questions such as: does this give meaning? Can I do it faster? (3) The evaluation process, contains decisionmaking about the process generated based on the results of thought and learning. For example, can I change the strategy that I use? Do I need a help? In this study, researchers focused on studying the characteristics of students' metacognition process which will be investigated from the process of planning, monitoring, and evaluation at each step of problem-solving.

\section{Informal Deduction Thinking Level in Solving Geometric problems}

The students' metacognition ability in solving geometry problems refers to metacognition ability in order to get more meaningful experience in learning geometric aspect and be able to actively construct their geometric knowledge from previous knowledge or experience that they have gained. The ability of geometric metacognition is more focusing on geometric ability and knowledge based on the level and process of development that students get through studying geometry. The theory of the development process used in studying the concept of geometry is Van Hiele's theory. Van Hiele states that in studying geometry, students are experiencing the development of thinking ability through certain levels. Van Hiele's theory is developed by two Dutch educators, Pierre Marie van Hiele and Dina van Hiele-Geldof, who explain the development of students' thinking in geometry (Mayberry, 1983). According to van Hiele's theory, someone will go through five levels of development thinking in learning geometry (Crowley, 1987). The five levels of van Hiele thinking development are level 0 (visualization), level 1 (analysis), level 2 (informal deduction), level 3 (deduction) and level 4 (rigor). This research is more focused on the level of informal deduction thinking.

Level of informal deduction, at this level it has been able to see the relation of properties of a geometry form and the properties of various forms by using informal deduction, and can classify on a form hierarchy. According to Crowley (1987) students at this thinking, level can already see the relationship of properties on a forms. For example, on a parallelogram parallel to the opposite side, the angles of the opposite are equal, as well as the relationship between multiple form such as, rectangles are rectangles because they have all the properties of rectangles. So at this level students are able to make abstract definitions, and provide informal arguments and classify forms with hierarchy. According to Crowley (1987) that the thinking geometry levels of Van Hiele have characteristics, namely (1) the level of thinking will pass the students in sequence. When students go through to a level, students have experienced geometric thinking at that level and have formed thoughts that will focus on the next level, (2) the level of thinking based on Van Hiele's theory does not depend on age, but depends more on content, methods and media learning of age and maturity. This is why teachers should provide learning experiences that geometry matches the students' thinking levels, (3) geometric experiences have a major influence on the rate of speed through a level.

\section{RESEARCH METHOD}

This research is a qualitative descriptive research. To obtain the research data, the researcher conducted several steps as follows: (1) give the test of geometry thinking ability of Van Hiele Geometry Test (VHGT) to 66 elementary students to determine the level of each student to be investigated. The geometric thinking test is

IJEME, Vol. 2, No. 1, March 2018, 89-104. 
structured on the characteristics of Van Hiele theory, where each level illustrates the thinking process applied in the geometric context. VHGT is a multiple choice test containing 25 questions compiled into the 5 levels of geometry thinking that Van Hiele conveyed. The geometry thinking test consists of 25 multiple choice questions, each level divided into 5 questions. Subtest level 0 (visualization) question number 1-5, level 1 subtest (analysis) question number 6-10, subtest level 2 (informal deduction) question number 11-15, level 3 (deduction) number 16-20 and subtes level 4 (rigor) question number 21-25; (2) analyze the geometry thinking test results and classify the students into groups based on the geometry thinking level; (3) select two students in the informal deductive thinking group to serve as the subject of the research study; (4) the subject solved the geometry problem according to the level of geometric thinking of informal deduction which previously validated by 5 mathematicians; (5) the researcher checks the subject's work result from the geometry problem; (6) after completing the geometry problems, the researcher conducted interviews on the subject to explore the students' characteristics and metacognition process in solving geometry problems by recording and writing the interview result.

Interviews were conducted semi-structured using interview guidelines that had been validated by mathematicians. The interview consisted of the problem-solving steps stated by Polya which understanding problem, making problem-solving plan, executing problem-solving plan, and checking the solution obtained and each problem-solving step has 3 metacognition indicators. Meanwhile, metacognition indicators in problem-solving consist of planning with 4 descriptors, monitoring with 4 descriptors and evaluating with 4 descriptors; (7) classifying data as a process of selecting and grouping data has a similar meaning if it is associated with students' geometric metacognition indicators; (8) data reduction by referring to the process of sharpening, classifying, disposing of unnecessary and organizing data obtained from interviews. Data reduction functions to remove unnecessary and less relevant and organize raw data obtained directly from the field to retrieve important data used in research; (9) present the data by writing organized data collection and categorized so that it is possible to do the conclusion of the resulting data. In this study, the authors present data by grouping metacognition process with code and chart so it is easy in describing and interpreting data; (10) interpret data by performing validity checks to determine the accuracy of data by using triangulation; (11) summarize the results of the study. Conclusions were obtained through the results of the students' work in solving the geometric problem-solving at the level of informal deduction thinking and interview transcripts.

\section{RESULTS AND DISCUSSION}

The research data is the result of the students' work in solving the geometry problem according to the level of informal deduction and the interview transcript result to analyze the characteristics of students' metacognition process in solving geometry problem through problem-solving indicator with metacognition process components consisting of planning, monitoring, and evaluation process.

The result of the geometry thinking ability test of Van Hiele's Geometry Test (VHGT) on 66 elementary students was to determine the level of each student which would be studied. It gained data that there are 41 students $(62 \%)$ at the visualization level, 14 students (21\%) at the analysis level, 5 students (8\%) at the informal deduction level, 1 student (1\%) at the deduction level, 5 students (8\%) are not at all levels of thinking and no students at the rigor thinking level. The dissemination of Van Hiele Geometry Test (VHGT) thinking ability test results is presented in Figure 1. 


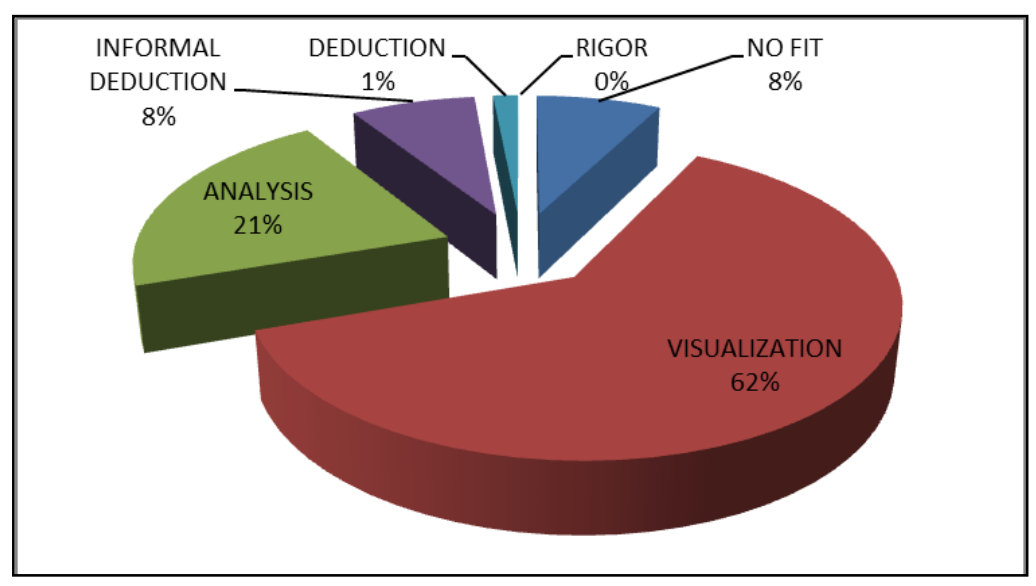

Figure 1. Diagram of geometry thinking level

Based on the analysis of the ability test of geometry thinking level, 6 students have the ability to think geometry in the informal deduction level. After triangulation done where each student has the same ability in one group and consult with the classroom teacher, two students (S-1) and (S-2) as the subject of the research is obtained. The next step is to solve the problem of geometric problem-solving at the informal deduction level. After the subjects complete the problem solving, then the next will be conducted an interview to find out and explore about the characteristics of the students' metacognition process in solving geometry problems. The interview consists of component steps of problem-solving by Polya with metacognition indicators of planning, monitoring and evaluating processes.

Steps to understand problems with metacognition indicators; (1) planning process, there are 4 descriptors that is thinking to know what is known (PP1), thinking what is asked (PP2), thinking to know the purpose of problem (PP3), thinking to express problem with their own sentence (PP4); (2) monitoring process, there are 4 descriptors that ask questions to himself about what is known (PM1), ask himself questions about what is asked (PM2), ask himself questions about the intent of the problem (PM3), monitor the sentences used for state the problem with his own sentence (PM4); (3) the evaluation process, there are 4 descriptors that decide whether the data obtained from what is known is correct (PE1), decide whether the data obtained from what is asked is correct (PE2), decide that the data about the meaning of the problem is correct (PE3) and decide that the sentence of self-made statement is correct (PE4).

Steps to prepare a problem-solving plan with metacognition indicators; (1) planning process, there are 4 descriptors that are thinking to look for data relation with what is known (RP1), thinking to look for possible formula / formula (RP2), thinking to find other solution as comparison (RP3), thinking to seek and select the initial knowledge in solving the problem (RP4); (2) monitoring process, there are 4 descriptors that ask questions to himself about data relation with what is questioned (RM1), choose the formula that may be used and adjusted with the obtained data (RM2), observe similar problem-solving step (RM3), ask himself about the initial knowledge used (RM4); (3) the evaluation process, there are 4 descriptors that decide the relationship between the data and the questioned is correct (RE1), decide which formula to use is suitable (RE2), decide the steps used on similar problem can be used (RE3) and decide what early knowledge is used to solve the problem (PE4). 
Steps to implement problem-solving plans with metacognition indicators; (1) planning process, there are 2 descriptors that are thinking to do the finishing steps correctly (LP1), and thinking to make improvement if there is error found (LP2); (2) monitoring process, there are 2 descriptors that ask themselves about the completion steps (LM1), and monitor the improvement measures if the error found (LM2); (3) the evaluation process, there are 2 descriptors that decide the completion steps are correct (LE1), and decide the corrective steps are correct (LE2).

Steps to check solutions obtained with metacognition indicators; (1) planning process, there are 4 descriptors that are thinking to check the results obtained (EP1), thinking to check whether the results obtained in accordance with the question (EP2), thinking to make improvements if there are errors (EP3), thinking whether the problem may be solved in different ways (EP4); (2) monitoring process, there are 4 descriptors that check whether the result obtained (EM1), check whether the results obtained are in accordance with the inquiry (EM2), check the improvement (EM3), check other ways used (EM4); (3) the evaluation process, there are 4 descriptors that decide the result check is correct (EE1), decide the result obtained is in accordance with the question (EE2), decide the repair is able to correct the error (EE3) and decide whether it can be solved in different ways (EE4).

Characteristics of the students' metacognition process in solving the geometry problem can be explained as follows:

\section{Students' Metacognition Process in Understanding Geometry Problems}

In solving geometry problems, S-1 and S-2 have relatively same characteristics of metacognition process in the step of comprehending the problem in sequence and complete from metacognition indicators that are planning process, monitoring and evaluation. When solving the geometry problem, the indicator that comes with the arrangement are PP1, PP2, PP4, PP3, PM4, PM1, PM2, PM3, PE4, PE1, PE2, PE3. While on S-2 with the arrangement of PP1, PP2, PP3, PP4, PM4, PM1, PM2, PM3, PE4, PE1, PE2, PE3. Explanation of each description and characteristic of metacognition process in understanding the problem can be seen in Figure 2 and Figure 3.

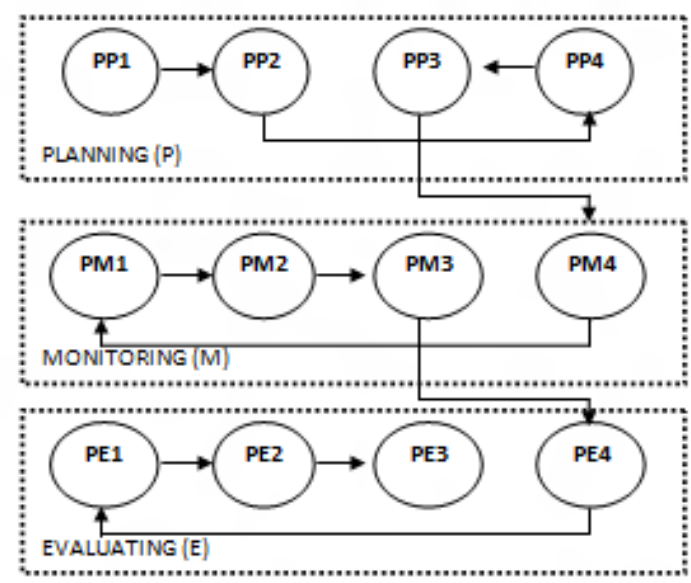

Figure 2. Metacognition process S-1

In the activity of understanding the problem, the S-1 and S-2 indicators appear on the components of the planning process, students start by thinking about what is known and questioned in the geometry problem on the concept of informal deduction. In the next level, S-1 thinks to make its own sentence to further simplify the intention of the problem so that 
it can more easily know the purpose of the problem, while the S-2 starts with thinking to determine the purpose of the problem then make a simple form of the problem. S-1 and S-2 have similarities in the monitoring and evaluation process components. In the process of monitoring, students re-monitor the sentences used in re-declaring the problem does not come out of the original intention of the problem. The sentence itself is used to re-monitor what is known, what is being asked so as to understand the purpose of the problem. In the evaluation process, students focus more on their decision to use self-made statement sentences to decide on data that are known and asked in the problem to decide the purpose of the problem that has been thought is correct.

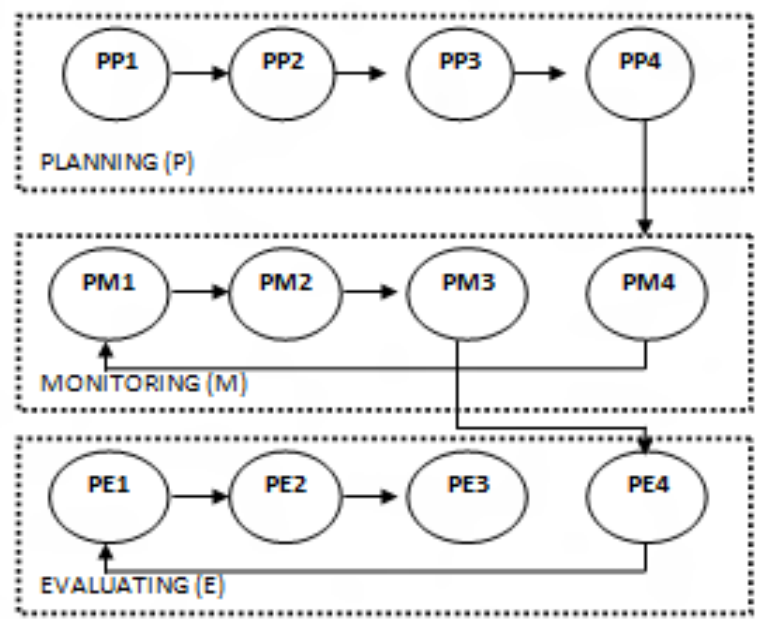

Figure 3. Metacognition process S-2

\section{Students' Metacognition Process in Preparing Geometry Problem-solving Plan}

Students with informal deductive thinking level showed the characteristics of metacognition process in the step of developing a complete geometry problem-solving plan from metacognition indicators; planning, monitoring and evaluating process. When solving geometry problems, the indicators that appear with the arrangement are RP4, RP1, RP3, RP2, RM4, RM1, RM3, RM2, RE4, RE1, RE3, and RE2. While on S-2 with the arrangement of RP4, RP1, RP2, RP3, RM4, RM1, RM2, RM3, RE4, RE1, RE2, RE3. Explanation of each description and characteristic of the students' metacognition process in preparing the problem-solving is shown in Figure 4 and Figure 5.

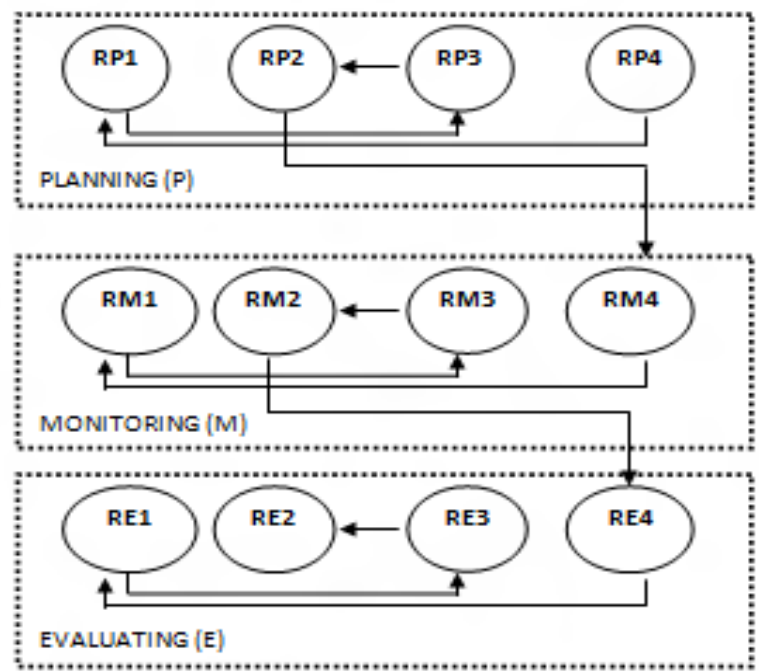

Figure 4. Metacognition process S-1

IJEME, Vol. 2, No. 1, March 2018, 89-104. 
In the activity of preparing the problem-solving plan, the S-1 and S-2 undertake planning activities by thinking of choosing the initial knowledge that can assist them in solving the problem. The initial knowledge is used to find the relationship between the data and the question. In S-1, the step is continued by thinking of finding a similar solution as a solution so that students will be able to find some formulas that might be used. In the monitoring process component, students ask themselves what initial knowledge needs to be used. In the evaluation process component, students are more likely to establish the initial knowledge used to solve the problem, then establish the data relationship with the problem. Meanwhile, the S-2 is more focused on thinking to look for alternative ways that may be used instead of looking for a solution similar problems as a comparison.

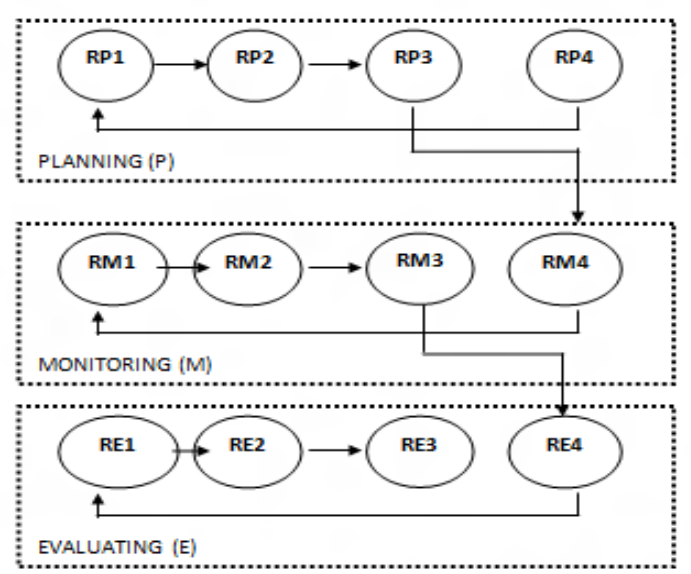

Figure 5. Metacognition process S-2

\section{Students' Metacognition Process in Implementing Geometry Problem-solving Plan}

At the step of implementing the geometry-solving plan, students with informal deductive thinking level demonstrate a complete sequence of characteristics process from the planning process, monitoring to evaluating. Sequentially the following indicators are LP2, LP1, LM1, LM2, LE1, and LE2. While on S-2 is LP1, LP2, LM1, LM2, LE1, LE2.

Explanation of each description and characteristic of the students' metacognition process in implementing the problem-solving plan is shown in Figure 6 and Figure 7.

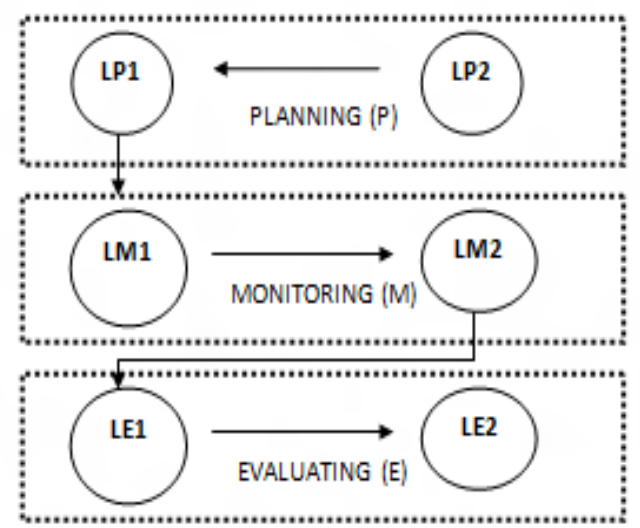

Figure 6. Metacognition process S-1 


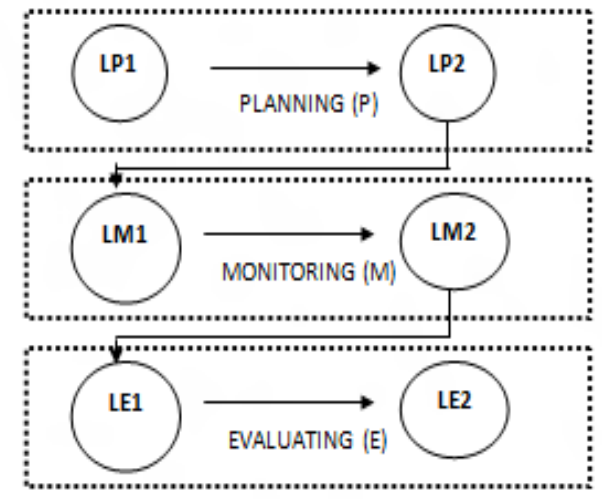

Figure 7. Metacognition process S-2

In carrying out the geometry problem-solving plan, students with the informal deductive level of thinking ability (S-1) showed the indicator that emerged in the planning process. The students would make improvements in advance if they found the mistake. Then the students did the steps of the settlement steadily. The S-2 prioritized more on thinking to perform the completion steps to make improvements if they found error. The similarity is shown by S-1 and S-2 in the process of monitoring and evaluation. The monitoring process demonstrated by the student by asking him/ her first about the problem-solving steps. In the next monitoring process, students monitor their remedial measures to find fault with the resulting solution. In the evaluation process, students are more focused on ensuring that their completion steps are correct and then decide to make improvements if they find error with the solution.

\section{Students' Metacognition Process in Checking Solutions Obtained}

In the step of re-examining the obtained solutions, S-1 and S-2 show the same sequence of process characteristics in sequence and complete from the planning process, monitoring to evaluation. Sequentially the following indicators are EP1, EP2, EP3, EP4, EM1, EM2, EM3, EM4, EE1, EE2, EE3, and EE4. The description of each description and characteristic of the students' metacognition process in reviewing the solutions obtained is shown in Figure 8.

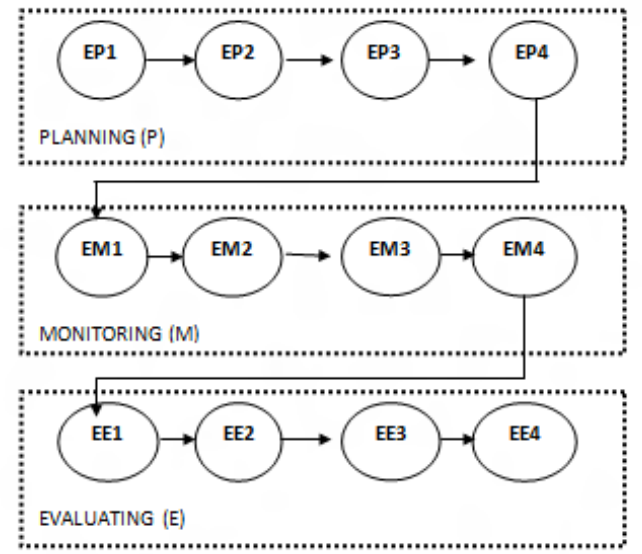

Figure 8. Metacognition process S-1 and S-2

In re-examining step, $\mathrm{S}-1$ and $\mathrm{S}-2$ indicate that the indicators appearing in the planning process are initiated by thinking of checking the results obtained. The examination is more focused on the conformity of the results with the problems asked 
and the corrective steps taken when the error is found. The results of the examination also provide reinforcement to students to think in solving in different ways. In the monitoring process, students tend to better monitor the results by taking into account data that are known and asked. The next monitoring, students think to make improvements if the fault is found and other ways that can be taken to solve the problem. While in the evaluation process, students with informal deductive thinking level are more likely to ensure and decide that the solution is correct by considering the suitability that is asked and known. All the characteristics of the students' metacognition process in solving geometric problems at the informal deductive thinking level can be explained in Table 1.

Table 1. Indicators and characteristics of the students' metacognition process in solving geometry problems

\begin{tabular}{|c|c|}
\hline \multicolumn{2}{|c|}{ Components of Understanding Problems } \\
\hline $\begin{array}{l}\text { Metacognition } \\
\text { indicators }\end{array}$ & Students' characteristics \\
\hline Planning Process ( PP) & $\begin{array}{l}\text { - Reading and thinking about what is known and } \\
\text { asked for the pictures and statements } \\
\text { presented } \\
\text { - Marking important words on issues as } \\
\text { keywords } \\
\text { - Examining changes in shape and forming } \\
\text { properties of the problem } \\
\text { - Making a statement with their own sentences } \\
\text { to further simplify the problem }\end{array}$ \\
\hline Monitoring Process ( PM) & $\begin{array}{l}\text { - Re-examining the sentences that have been } \\
\text { made by noticing to the image changes in the } \\
\text { form of space with changes in properties } \\
\text { - Re-monitoring keywords as known and asked } \\
\text { concepts } \\
\text { - Connecting between the form (I) along with its } \\
\text { nature and the shape of the form (II) and its } \\
\text { properties. }\end{array}$ \\
\hline
\end{tabular}

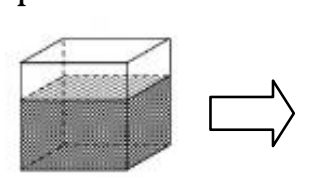

( I)

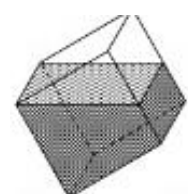

( II)

- Monitoring any change of the form and its nature is adjusted to the image and statement.

Evaluating Process ( PE ) - Setting simple sentences that are made to serve as concepts in answering the problem

- Defining the elements in the image and keywords in the statement as something known and asked

- Ensuring the purpose and objectives of the problem which considered true 


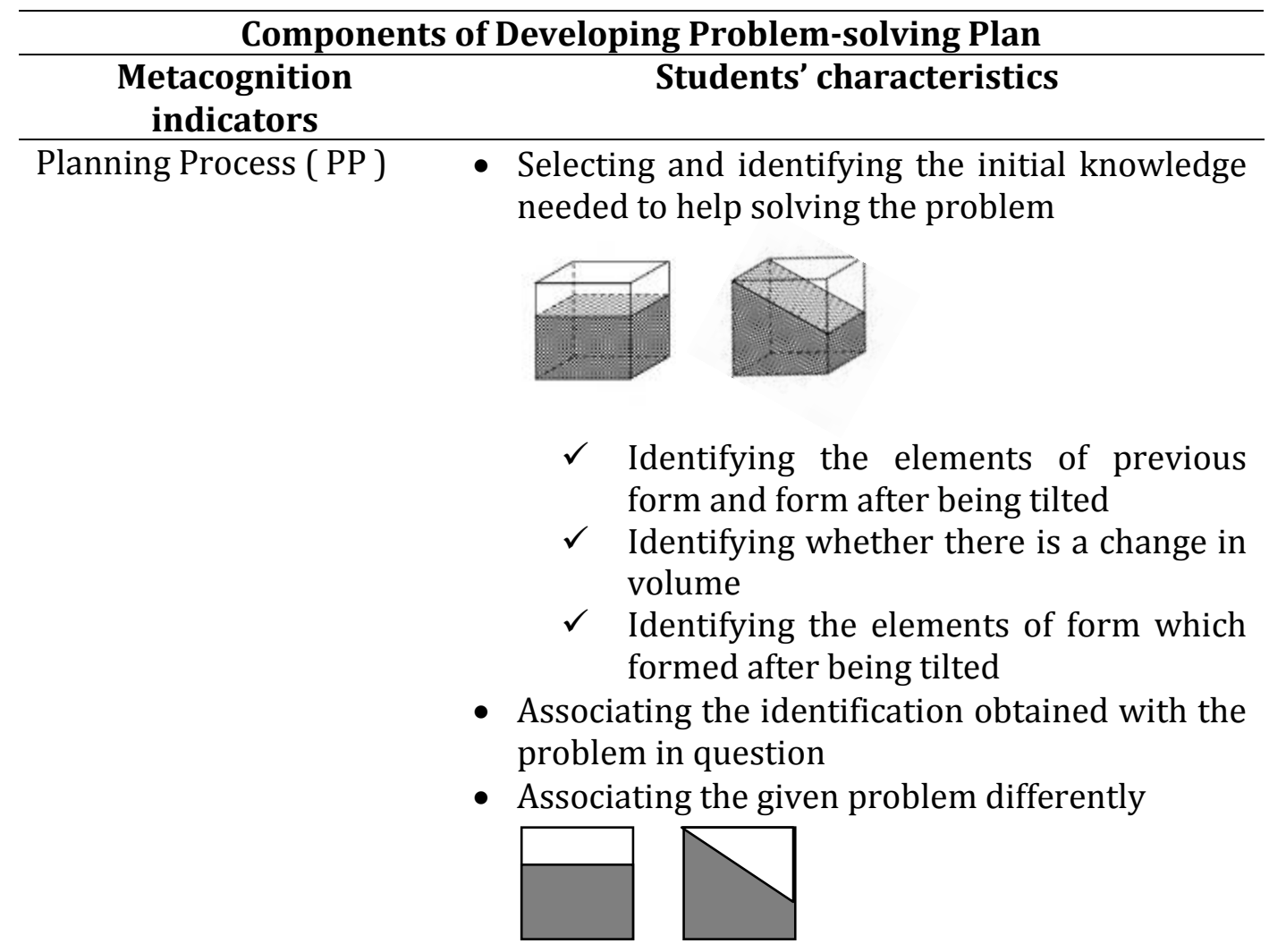

- Noticing the form that is not shaded from the surface of the form

Monitoring Process (PM) - Monitoring some initial knowledge that is appropriate to the problem

- Re-monitoring the relationship of the initial knowledge with the problem

- Reflecting on different ways that might be resolved

Evaluating Process ( PE ) • Establishing the elements at each form and the fluid properties that make form as initial knowledge

- Determining the relationship of the elements and the nature of the fluid that make form with the build properties that are formed

\begin{tabular}{|c|c|}
\hline \multicolumn{2}{|c|}{ Components of Problem-Solving Plan Implementation } \\
\hline Metacognition Process & Students' Characteristics \\
\hline Planning Process ( PP) & $\begin{array}{l}\text { - Making improvements to the concepts needed } \\
\text { to solve the problem. }\end{array}$ \\
\hline
\end{tabular}




\begin{tabular}{|c|c|}
\hline & $\begin{array}{l}\text { Form volume (I): the parallel ribs formed is the } \\
\text { same length and all the fields that make up the } \\
\text { form are rectangular } \\
\text { Form volume (II): it has } 12 \text { ribs that are not the } \\
\text { same length and there are } 2 \text { trapezoids which are } \\
\text { opposite and similar. }\end{array}$ \\
\hline Monitoring Process ( PM ) & $\begin{array}{l}\text { - Monitoring a resolution that has been thought } \\
\text { and adjust to the known issues and data } \\
\text { - Observing any data needed to know the fault } \\
\text { for completion }\end{array}$ \\
\hline Evaluating Process ( PE ) & $\begin{array}{l}\text { - Deciding that based on the observed and } \\
\text { monitored traits it is established that } \\
\text { Form (I) is a block } \\
\text { Form (II) is a trapezoid prime } \\
\text { With the change of nature from form (I) to form } \\
\text { (II) } \\
\text { - Deciding that the volume of fluid in form (I) and } \\
\text { (II) is unchanged and it only changes in the } \\
\text { shape of the form }\end{array}$ \\
\hline \multicolumn{2}{|c|}{ Components of Re-Checking Solutions obtained } \\
\hline $\begin{array}{l}\text { Metacognition } \\
\text { indicators }\end{array}$ & Students' characteristics \\
\hline Planning process ( $\mathrm{PP}$ ) & $\begin{array}{l}\text { - Checking the problem-solving by adjusting the } \\
\text { results obtained with the problem } \\
\text { - Repeating the data that are known and asked } \\
\text { until the results obtained to be reinforced } \\
\text { - Checking for the possible improvements from } \\
\text { the solution }\end{array}$ \\
\hline Monitoring Process ( PM ) & $\begin{array}{l}\text { - Re-examining the problem-solving by noticing } \\
\text { the data that is known and asked } \\
\text { - Monitoring the initial concept as a } \\
\text { reinforcement of the results obtained }\end{array}$ \\
\hline Evaluating Process ( PE ) & $\begin{array}{l}\text { - Deciding that the results obtained are correct } \\
\text { - Convincing himself that the results are in } \\
\text { accordance with the problem }\end{array}$ \\
\hline
\end{tabular}

Based on the characteristics sequence of the students' metacognition process in elementary school at the level of informal deduction thinking in solving the problem of geometry, it raises some findings that becomes special characteristics, among others: (1) students focus more on the full visibility and the visualization form in the prior knowledge in determining the concepts (2) more students need a picture to relate visualization to the statement, (3) many students need prior knowledge and experience to analyze the form in terms of its components so as to determine the nature of the form, (4) students have understood the relation of the character of a substance that influences the changes of shape. Suppose that the liquid nature follows the shape of the container and the shape formed so that the student can conclude that 
the liquid in the form will also create a new form, (5) on the development of the student's knowledge through problem-solving with informal deduction, the student has been able to give the argument logically by simply proving the concept of form changes by their nature with their own sentences.

The findings of this research are the development of Clements and Battista (1992) research which states that elementary students can understand the concept and identify the triangular, rectangular and square triangular waves reaching $68 \%$ 87\%. Similar research was also conducted by Abdullah and Zakaria (2013) which states that there are different ways of understanding and mastering concepts at every level of Van Hiele geometry. While in this study, elementary students are able to understand the concept of plane, determine its properties to determine alternative hypothesis and work procedures through the way of informal deduction. Informal deductive ways of thinking that students do through the levels of visualization, analysis, hypothesis, testing the hypothesis, linking hypotheses with data to conclusions.

The findings of this study also corroborate In'am (2016), Purnomo et al. (2016) and Purnomo et al. (2017) studies which suggest that students with high and medium capability have complete metacognition characteristics at each level. This means that elementary students in the informal deduction phase have metacognitive characteristics that are complete with medium or high math skills. The statement can be proven by completing the complete phase of metacognition process of students at each level.

\section{CONCLUSION}

Based on the data analysis and the characteristics sequence of metacognition process, it can be concluded that elementary school students at the level of informal deduction thinking level have a complete sequence of metacognition process through planning, monitoring and evaluating process in solving problems. The metacognition process indicator appears in each problem-solving component starting from understanding the problem, preparing a problem-solving plan, implementing a problem-solving plan, until checking the solutions obtained. The metacognition process that emerges from the students at the informal deductive thinking level is focusing more on planning to cultivate their understanding and knowledge in the form of full visibility and visualization of problems into simpler forms. In the monitoring process, students are more likely to base visual knowledge monitoring to relate their initial knowledge to the problem. In the evaluation process, students choose and identify alternatives that can be used to decide the result of problem solving.

Characteristics arisen from the students' metacognition process at the level of informal deduction thinking level is the emergence of the ability of visualization and students' analysis in determining the initial knowledge to be associated with the problem. This is in accordance with Crowley (1987) who states that the students' geometry thinking levels are passed in sequence and formed thinking that will focus on the next level of thinking. The level of informal deduction thinking is the thinking level of development from the level of visualization thinking and analysis. An important step that should be an addition of the problem-solving component to the student in solving the geometry problem is the preparation of hypotheses and working procedures. In line with the statement stated by Gagne, he says that the preparation of alternative hypotheses and working procedures becomes an important step in problem solving. This means that additional steps are needed, namely the

IJEME, Vol. 2, No. 1, March 2018, 89-104. 
hypothesis of visualization and hypothesis of analysis. A visualization hypothesis is needed to give a complete picture as a way to manipulate a temporary answer before it is deduced. The analysis hypothesis is needed to connect the visualization hypothesis to the understanding of the problem nature. The characteristics of students at the level of informal deduction thinking can also provide an overview of the students' ability in answering the problem of volume conservation presented by Piaget. Children at the concrete operation level can know that the water volume remains the same even though it is transferred into different containers. The nature of inversion, reciprocity and identity occurs in students with informal deductive thinking skills.

\section{REFERENCES}

Abdullah, A.H., \& Zakaria, E. (2013). Enhancing Students' Level of Geometric Thinking through Van Hiele's Phase-based learning. Indian Journal of Science and Technology. 6(5), 4432-4446.

Clements, D.H., \& Batitista. (1992). Geometry and Spatial Reasioning. New York: MacMillan Publisher Company.

Crowley, M.L. (1987). The Van Hiele Model of Development of Geometric Though. Reston, VA: National Council of Teachers of Mathematics. K-12, 1-16.

Duffin, J.M., \& Simpson, A.P. (2000). A search for understanding. Journal of Mathematical Behavior, 18(4), 415-427.

Foong, P.Y. \& Ee, J. (2002). Enhancing the learning of underachievers in mathematics. ASCD Review, 11(2), 25-35.

Haryani, S. (2012). Pengembangan Mahasiswa Model Praktikum Kimia Analitik Instrumen Berbasis Masalah Untuk Meningkatkan Metakognisi Mahasiswa Calon Guru. Doctoral dissertation. Bandung: UPI.

Ikhsan, M. (2008). Meningkatkan Prestasi dan Motivasi Siswa dalam Geometri melalui Pembelajaran Berbasis teori Van Hielle. Doctoral dissertation. Bandung: UPI.

In'am, A. (2012). A metacognitive Approach to Solving Algebra Problem. International Journal of Independent Research and Studies, 1(4), 162-173.

In'am, A. (2016). Euclidean Geometry's Problem-solving Based on Metacognitive in Aspect of Awareness. IEJME-Mathematics Education, 11(4), 961-974.

Kafoussi, S. (2013). Elementary Students' Spontaneous Metacognitive Function Different Type of Mathematical Problems. Journal Research in Mathematics Education (Online), 2(2), 242-267.

Karan, E.P., \& Irizarry, J. (2011). Effects of Metacognitive strategies on Problem Solving Ability in Construction Education. Proceedings of the 50th ASC Annual International Conference, Retrieved from http://www.ascpro.ascweb.org

Kuzle, A. (2011). Pattern of Metacognitive Behavior During Mathematics Problem Solving in a Dynamic Geometry Environment. International Electronic Journal of Mathematics Education, 8(1), 20-40.

Latifah L.N. (2010). Pengaruh Model Pembelajaran Kooperatif Tipe Co-Op Co-Op terhadap Peningkatan Berpikir Kritis dan Ketuntasan Belajar Matematika Siswa SMA Bandung. Doctoral Dissertation. Bandung: UPI.

Livingstone, J.L. (1997). Metacognition: An Overview (On Line), Retrieved from 
http://www.gse.buffalo.edu/fas

Matlin, M. (1998). Cognition. Philadelphia: Harcourt Brace College Publisher.

Mayberry, J. (1983). The van Hiele Levels of Geometric Thought in Undegraduate Preservice Teacher. Journal for Research in Mathematics Education, 14(1), 58-69.

Panaoura, A. (2009). An Intervention to the Metacognitive Performance: SelfRegulation In Mathematics and Mathematical Modeling. Acta Didactica Universitatis Comenianae Mathematics (online), 9, 63-79.

Pierce, W. (2003). Metacognition: Study strategies, monitoring and motivating. A workshop paper presented at Prince George's Community College. Retrieved from http://academic.pg.cc.md.us

Polya. (1973). How to solve it. New Jersey: Princeton University Press.

Purnomo, D., Nusantara, T., Subanji, \& Rahardjo, S. (2016). Metacognition Process Characteristics of the Students in Solving Mathematics Problems. IOSR Journal of Research and Education (IOSR-JRME), 6(5), 26-35.

Purnomo, D., Nusantara, T., Subanji, \& Rahardjo, S. (2017). The Characteristic of the Process of Students' Metacognition in Solving Calculus Problems. International Education Studies, 10(5), 13-25.

Schoenfeld, A. (1992). Hand Book of Research on Mathematics Teaching and Learning. New York: Mc Millan Co.

Suherman, E. (2001). Strategi Pembelajaran Matematika Kontemporer. Bandung: JICAUniversitas Pendidikan Indonesia.

Weldana, H.N. (2014). Gender Position and High School Student's attainment in Local Geometry. International Journal of Science and Mathematics Education, 13(6), 1331-1354

Wilson, J., \& Clarke, D. (2004). Toward the Modelling of Mathematical Metacognition. Mathematics Education Research Journal, 16(2), 25-48.

Woolfolk, A. (2008). Educational Psychology (9th ed). Boston: Allyn and Bacon.

Yeo, J.K.K. (2004). An exploratory study of secondary two students' mathematics anxiety and mathematical problem solving. Doctoral Dissertation. Singapore: National Institute of Education.

Zainal, Z., \& Tajudin, N.M. (2013). Metacognitif process in Solving non-routine Mathematics Problems. Retrieved from http://www.psmm.upsi.edu.my 